\title{
Evolution as an Unwrapping of the Gift of Freedom
}

\section{TOM MCLEISH FRS}

Department of Physics and Humanities Research Centre, University of York tom.mcleish@york.ac.uk ORCID: 0000-0002-2025-0299

\begin{abstract}
Extending the approach to a 'theology of science' developed in Faith and Wisdom in Science (McLeish 2014), I expand its theme of the tension between chaos and emergent order, within the arc of the Biblical story of creation, towards a theology of evolutionary science. In addition to the material in Job, the book of Wisdom provides a remarkable account of transmutation of species, within a recapitulation of the Exodus theme, that I reconsider as a background historical narrative to an interpretation of modern genotype-phenotype theory of evolutionary dynamics, exploiting analogies with statistical mechanics. The dual and connected structures of microscopic and macroscopic provide a contemporary locus for the Joban tensions of chaos and emergent order, and provide an interpretative narrative for the emergent directionality of evolution, and a theology that situates within a creation of freedom to explore the potential of the created order.
\end{abstract}

Keywords: theistic evolution; Wisdom; genotype-phenotype map; statistical mechanics; emergence; theodicy.

\section{Introduction: A Theology of Science, Joban Wisdom and Random Processes}

In recent work (McLeish 2014), I attempted to draw on the tradition of biblical wisdom, taking a starting point in the book of $J o b$, to formulate directions towards a 'theology of science'. By that term I meant to suggest 
a teleological account, within the Judeo-Christian tradition, that asks to what end homo sapiens receives the gift of science within the Kingdom of God to which, within that narrative, humans are called to live and flourish. The framing category - of science as gift rather than as threat to the church - is deliberately distinctive to a large body of writing in 'science and religion' that takes as a starting assumption that any question under that heading is one of apologetics. A theology of science (as opposed to any negotiation between theology and science) attempts to formulate its account of gift that does justice, on the one hand, to the long biblical narrative arc of relationship between humans and their material world, and on the other, to the extraordinary capacity of human beings to discover the hidden structures of that world (McLeish 2014) that modern science has amplified (though by no means discovered for the first time). I concluded that the human activities and aptitudes that now go under the name of 'science' are the current manifestation of a long cultural stream whose continuity is sometimes disguised by different nomenclature in earlier ages. Furthermore, that the 'natural philosophy' of medieval and early modern periods points to the notion that primary biblical source material should be sought within its wisdom corpus. As did Susan Neiman (2016) in the case of moral philosophy, I found that for the case of natural philosophy as well, the book of Job presents the richest seam of Hebraic sources that flowed alongside the Hellenic, via a complex course of reception, into modern thought. The interim conclusion of a close reading of $J o b$ (and the extensive corpus of Old Testament creation stories) through a New Testament lens, and an honest appraisal of the experience of science within society, was that scientific imagination, desire, aptitude and history can be framed as a gift towards the restoration of a relationship - in this case the broken relationship between humankind and the rest of the material creation (McLeish 2014). It is worth underscoring that to draw on themes from Job by which to think about the human, social and theological consequences of science, is not to impute or read-back modern notions of science, physical law or cosmology into the ancient book. It does, however, recognise (along with Neiman) that Hebrew thinking in general, and the book of Job in particular, has been repeatedly 
drawn on, both explicitly and implicitly, in the philosophical tradition of the West. This is a point well-made also by David Clines in his magisterial edition, translation, survey and commentary series on Job (and from which most of the textual, translational and hermeneutic material below is taken), when he writes: 'the history of a work's "reception," we are belatedly coming to realise, is part of the meaning of the work.' ${ }^{1}$

It is as common to confine Job into the neat category of theodicy as it is to limit 'science and theology' to apologetics, yet this ancient wisdom book is far more than that (Batnitzky and Pardes 2014). Job's parallel argument that the natural world is out of its Maker's control, as much as is the moral world, says just as much about the relationship of the human to the materiality of nature as it does to a theology of suffering (Sinnott 2001). The long-awaited 'Lord's Answer' of chapters 38-42 surveys nature with searching (and deeply meaningful) questions of process and governance, but tellingly without making mention of any domesticated domain (Habel 1985). It ranges instead over the wild and untamed in the animal, astronomical, geological and meteorological worlds. The natural objects of the questions within the Book of Job are of turbulent, rather than laminar, flow, of lightening rather than glow-worms, of the mountain lioness rather than sheep and goats, suggesting a complementary approach to the human relationship with nature, one distinctively different from the canonical narrative of domestication that takes Genesis (1:28) as its starting point (Habel 2001).

To take one example, Job's closing thrust at the end of the first cycle of speeches between him and his friends sustains his argument for the illusory nature of hope ${ }^{2}$ by contrasting two natural phenomena. The first is the phenomenon of regeneration from a the stump of a felled tree (Job 14:7-9):3,4

Clines (1989) p. xxx.

2 תקוח ('hope' lit. a cord or tie) recurs nine times in Job 7-19, but only three times in the rest of the book. To 'destroy man's hope' (14:18-19) therefore draws on the metaphor of being cut-off (e.g. from a mountainside).

3 We take quotations of the text from translation and commentary by David Clines (1989, 2006, 2011), World Bible Commentary 17, 18a, $18 b$ (Job), Thomas Nelson and Sons.

4 Cf. H.H. Rowley, Job. NCB. Thomas Nelson \&Sons (1970): 'Why, Job asks by implication, should man be denied what is granted to a tree?' 
At least there is hope for a tree: if it is cut down, it will sprout again, and its new shoots will not fail. Its roots may grow old in the ground and its stump die in the soil, yet at the scent of water it will bud and put forth shoots like a plant.

The second is a natural idea very rare in the ancient world (but not entirely absent - Lucretius refers to it in his de rerum natura ${ }^{5}$ ). Job summons the properties of 'deep time' eroding through the ages the apparently (to humans) permanent structures of the earth (Job 14:18-19):

Yet as a mountain slips away and erodes, and a cliff is dislodged from its place, as water wears away stone and torrents scour the soil from the land - so you destroy man's hope.

Commentators are divided on how this 'hopeless' aspect of nature should be read against the 'hopeful' phenomenon of the tree-shoot. ${ }^{6}$ Do both or neither refer directly to the natural world as well as working in their clear metaphorical mode? Is one rather than the other more significant of Job's currently nihilistic analysis of his predicament? There is no reason to favour either usage - we know that the writer of Job is highly sensitive to natural phenomena, and to the human desire to ask questions of them, even to draw meaning for them (McLeish 2014). It is rarely pointed out, for example, that all of the natural phenomena appearing in the Lord's Answer at the close of the book are reprises ${ }^{7}$ - they have already been invoked within the

5 There is a surviving record of an extended debate between Lucretius and Theophrastus on the finite or infinite history of the world in which Lucretius appeals to the erosion of mountains to support the necessity of a finite history, "Do we not see rocks roll down, torn from high mountains, unable to endure the mighty force of a finite timespan? For they would not suddenly be torn away and fall if they had from infinite time past suffered without damage all the harsh treatment of ages." Lucretius, De rerum natura v315-317.

6 Clines (op. cit.) takes the intended referent to be entirely human hope, suggesting that if the collection of natural phenomena did refer to the world, they would contradict. Habel (1985), however, insists that a failure to take the nature metaphor seriously misses the irony of noticing that water (in the form of the necessary emendation 'rainstorm', which vivifies the flowers of 14:2 yet erodes the rocks that elsewhere are the Biblical symbol of permanence (Gen 49:26).

7 But see L. Steiger (1965), 'Die Wirklichkeit Gottes in unserer Verkündigung,' in Festschrift H. Diem (München) who takes the extreme view that the Voice from the Whirlwind adds nothing to the earlier dialogues. A more moderate position is advanced by T.F. Dailey 
three incomplete cycles of speeches by which the book is constructed. The author of Job is also deeply aware of the ambiguity of the natural world in relation to humankind, both in its direct physical channels (rain irrigates crops but also destroys them) and in the conceptual and reflective (the human mind can begin to grasp at an understanding of the world, even of the processes of time unimaginably longer than a human lifespan, but the vast ocean of nature's mysteries elude it). ${ }^{8}$ Furthermore, when we look for meaning in the world, we witness as much chaos as order, as much tearing down as building up. At this stage in the argument Job can agree with his friends on one point: there is indeed a moral law woven into the physical fabric of the world that patterns the physical laws that operate there, and one that works equally within the material of the human body itself, but it is not the well-ordered law of just rewards, but rather a chaotic 'non-law' of ultimate decay and purposelessness.

At the heart, therefore, of the biblical text most resonant with natural philosophy in terms of its subject matter and questioning approach, ${ }^{9}$ there is an explicit theme of random process, the aleatory, the chaotic in nature. This makes remarkable reading for a scientist today, for whom this very substrate of random motion, choice and concomitant unpredictability has become, from statistical physics to evolutionary biology, a common currency of scientific understanding of the world. Again, this is not to read back into Job a concept from late modern science, but to recognise that

OSFS (1994), The Repentant Job, Lanham: University Press of America, as an. 'awakening [of Job] to something "more” than he had heretofore known' (p.103). Alter (1985) demonstrates that both imagery and philology of ch. 38 respond and reflect those of ch. 3 in detail.

8 E.g. Gordis, Robert (1985) The Book of Job: Commentary, New Translation and Special Studies. New York:KTAV, p.560, 'The thinker calls upon Job to grasp the world and recognize man's limitations [...] in a world that is miracle as well as mystery.'

9 Not, of course, beyond this in any anachronistic sense that the book embeds any modern notion of philosophiae naturalis, but that the deep questioning of nature in chs. $38-40$ cannot be merely remonstrative, but implies and educative and invitational engagement. See McLeish (2014) but also other scholarship e.g. Lévêque, Job et son Dieu, p.513: 'Yahweh lui offre une joute sapientielle; et ce déplacement de l'axe du dialogue atteste à la fois l'intention éducative de Dieu et sa volonté de ne pas entrer dans le système d'images ou Job s'est enfermé'. 
the "metaphors we live by"10 in science draw on a narrative tradition with ancient roots that we do well to uncover. In Faith and Wisdom in Science I drew heavily on the significance of Brownian Motion - the seething, fluctuating random motion of the underlying molecular components of matter that accounts for the emergent property we call 'heat'. Not only that, but the phases of matter themselves, the solid, liquid and gaseous forms of the same material elements owe their natures and their transitions to this substrate of randomness. Even properties such as 'softness' and 'brittleness' emerge, not only as a function of the molecular constituents of matter, but from the amplitude of these microscopic motions (as charted by another emergent property: temperature). An understanding of how predictable, ordered structure and behaviour at the macroscopic scale emerged from a microscopic world of disorder, is one of the most remarkable achievements of physics over the last century and a half. It is therefore remarkable to find the same question, framed appropriately in contextual language and knowledge, as a fundamental part of the tension set up in Job. The Lord's answer (composed, as we have noted as questions) takes up and addresses Job's complaint of a natural world out of control through the idea of a 'way'(דרך) or 'channel' (Job 38:24):

Where is the realm where heat is created which the sirocco spreads across the earth? Who cuts a channel for the torrent of rain, a path for the thunderbolt?

The point for the writer of $J o b$ is that the chaotic forces of wind, flood or lightning are not utterly lacking in control, but on close inspection are endowed with pathways to follow. ${ }^{11}$ Using contemporary scientific language to comment on the same phenomena, we might say that local chaos can give rise to large-scale structure when there are additional constraints, that creation harnesses the power of random forces without suppressing them,

10 Lakoff, George and Mark Johnson (1980), Metaphors We Live By, Chicago: Univeristy of Chicago Press.

11 So e.g. Habel (1985) p.542: “The repetition of the term "way" (derek) (דרך) within the neat inclusion structure of 38:24-25 emphasizes that both lightning and thunder have a fixed course which governs their movements.' 
but rather by directing them into paths and processes, even extending to the processes of life itself. A living cell, after all, if cooled to the temperatures at which Brownian Motion calms significantly, simply freezes and dies. Life requires the substrate of random molecular motion.

There is another natural process that falls, as far as we know, into the category of ordered large-scale structure emergent from random small-scale dynamics: that of the evolution of life itself. The analogy to the Brownian Motion of material is conceptually a close one, albeit hidden by analogy, for the microscopic dynamics of evolution occurs, in the first place, at the level of the coding molecule of DNA, and in the second place not by its spatial displacement, but by the random genetic mutations by which the copy bequeathed by an organism to its descendants is slightly different from the one it inherited from its ancestors. The equivalent in this analogy of the macroscopic material properties is the developed organism for whose development and function the DNA codes. In some limits of (slow) mutation rate and limited population size, the analogy between evolution through random mutation of a 'genotype' within a fitness determined by the 'phenotype' of the organism, and statistical mechanics (the molecular theory of thermodynamics) can even be shown to be mathematically exact (Barton and Coe 2009).

From the very earliest days of evolutionary ideas, of course - the famous Oxford debate between Huxley and Wilberforce is perhaps an overblown example (Brooke 1991) - there have been extended discussions, recorded in a vast literature, on the theological implications of evolution (see Brook 1991, Barton and Wilkinson 2009, and Russell 2013 for excellent single-author, edited and recent surveys). In the face of such an understatement, one adds to this corpus with some nervousness. However, I have not found any that draws on both the strong analogy with statistical mechanics from the scientific perspective, and the tradition of Joban and other wisdom tradition from the theological, to explore possible reframings of evolutionary science within the wider project of a relational 'theology of science'.

That is the path on what this article attempts to locate some initial signposts and directions, but before embarking upon it a word on method- 
ology is perhaps helpful. As in the overall project of Faith and Wisdom in Science, the project sets different texts and traditions, in the broadest sense, into conversation with each other. Although in the eyes of some, a modern scientific account of evolution, and a set of ancient texts, might be ostensibly 'incommensurable', there is typically much more to articulate than such first impressions allow; this is done in the spirit of Paul Ricoeur (1991) in which each framework's theory is permitted to accommodate the insights of the other, within a third, larger framework of questions in the mind of a contemporary reader familiar with both. In this case those questions are historical and teleological. They may draw from reflection on human relationship with the natural world from any age and tradition suitably contextualised, in deriving both commonalities and differences in a long story of why human beings have attempted to represent and understand the material world. They inform the cultural backdrop of our motivation to do science today, within which theological narratives have always played a vital and formative role (Harrison 2015).

\section{A Scriptural Account of Transmutation of Species}

One reason for beginning, in the Faith and Wisdom in Science project (McLeish 2014), with a close reading of $J o b$, held in close juxtaposition with an account of the experience of doing science, before any work of analysis or theology, was an uneasiness at the relative lack of confrontation with biblical tradition in canonical 'science and religion' literature. Its own approach, while being careful to locate and respect all writing in its own time and predicament, and starting with the wisdom tradition, then permits the work of science-theology to be situated within the narrative arc of creation, fall, election, incarnation and resurrection that has structured Judeo-Christian thinking and counter-culture, with consequently less temptation to impose modern categories of metaphysics on the long history of human confrontation with nature.

The story of $J o b$ will be always in the background, with its simultaneous insistence on unanswered questions of nature and yet the appropriateness of 
asking them, and its urging of reconciliation with wildness and wilderness. However there is another, albeit much later and deutero-canonical, passage from the book of Wisdom (or in Greek tradition, Wisdom of Solomon) that might have received more attention than it has as a literary precedent for an idea connected with later science, in this case the notion of transmutation of species. The closing verses of the book run (Wisdom 19:18-21 trans. Jerusalem Bible):

A new attuning of the elements occurred, as on a harp the notes may change their rhythm, though all the while preserving the same tone; and this is just what happened: land animals became aquatic, swimming ones took to the land, fire reinforced its strength in water, and water forgot the power of extinguishing it;

flames on the other hand, did not char the flesh or delicate animals that ventured into them;

nor did they melt the heavenly food resembling ice and as easily melted.

This is an astonishing conclusion to an extended account, starting in chapter 10, of the Exodus of Israel from Egypt, retold as a series of 'antitheses' recounting the story of the plagues and passage through the Red Sea. The biblical narrative is mixed with other material from the neo-platonic, probably Alexandrian, milieu of the writing, appearing in the manifestly Hellenic scheme of the elements of fire, air, earth and water in this final passage (as well as earlier). The entire book of Wisdom is, like Job before it, consistently natural philosophical ${ }^{12}$ in tone (Goff 2007). Before the extended recapitulation of the Exodus is an admission of the widespread guilt of idolatry, for example, but in this context tellingly framed as a misplaced relationship between humans and nature (Wisdom 13:1-5), that forms the central pivot of the book:

12 See note 9 above, and also Goff Discerning Wisdom, p.124: 'It is implicit that nature is a source of wisdom for the addressee'. 
Yes, naturally stupid are all who are unaware of God, and who, from good things seen, have not been able to discover Him-who-is, or, by studying the works, have not recognised the Artificer. Fire, however, or wind or the swift air, the sphere of the stars, impetuous water, heaven's lamps, are what they have held to be the gods who govern the world.

In this early confrontation of Hebrew wisdom with Hellenistic philosophy, what emerges is much more subtle and interesting than mutual refutation or condemnation. The Aristotelian cosmos hangs unchallenged in the background, as much as its elemental theory threads through the text as simply assumed. Yet the foreground material is as thoroughly Judaic in its extended meditation on the Exodus theme as, say, Psalm 105. The only warning delivered to those contemplating the workings and structure of nature, is not to mistake the created things as themselves divine, not to confuse the created with the Creator. But there is more to this fusion of wisdom and philosophy - a most surprising merging of narratives: for the multiple material changes in the natural order required to arrange the freedom of God's people from slavery are interpreted though the lens of Hellenistic thought as a divine alteration at the level of elemental physics. It works through a particular example of macrocosm-microcosm parallelism, except that here the 'microcosmic' domain is really elemental, not even creaturely. Furthermore, the new 'attuning of the elements' and its explicit musical analogy of the world as an instrument upon which the Creator plays, releases the possibility of continuous creation. This is explicit a little earlier in the chapter (v.6), For the whole creation, submissive to your commands, had its very nature recreated. In a fugue on themes that return to the earliest pre-Socratic notions of theories of limited change (the reason for elemental theory in the first place), the writer of Wisdom introduces a type of material change that goes beyond an Aristotelian remixing of elemental proportion to a shift in the relative properties of the elements themselves, now re-interpreted as a Hebraic re-creation (Winston 1971).

This conversation between, and synthesis of, traditions is the context in which such cosmic shifts in the register of physics are reflected at the 
biological level. As water becomes earth (an Aristotelian elemental translation of the Exodus phenomenon of the sea becoming dry land) so its marine animals are imagined to mutate into land-dwelling ones, and vice versa. Of course, this is assuredly not in any form an anticipation of the Darwinian evolutionary transmutation of species. However, it marks in literary form an imaginative affirmation, originating in or before the first century BCE, that creation possesses the potential to change at its deepest structural levels, including the properties of physical elements and biological species.

It is surely not without significance that a discussion of the unfolding of such deep shifts in the physical and biological worlds emerges from a historical/theological discussion of the Exodus. The framing story recounts the Hebrew archetype for the archetypical release from slavery into freedom. By and through the natural dislodging of the world-order itself, as much as through theo-dramatic and political acts, Moses leads the Israelites out of captivity through water and into (a generation later) a renewed relationship with the Promised Land. The theme of exploration of freedom within constraints enjoys, in Wisdom, an explicit parallelism between the history of People and the emergence of new orders of Creation. Whether the text admits of a first creation ex nihilo, or from 'formless matter', though an important and interesting question (Winston 1971), is not of immediate relevance to this issue of continuous creation, for such a process always takes existing matter as its starting point. The new point is that the emergent shifts in high-levels of organisation (e.g. mutation of animal species), while supported in terms of 'material cause' by elemental shifts at the microscopic scale, may demonstrate, according to the writer of Wisdom, a recognisable order - in this case the mutual exchange of marine and land accommodation. Furthermore such reordering of nature is held in parallel with, nested within, and reflective of, a narrative in which the carriers of free agency in the created world are enacting that freedom in a new way following the release of long-imposed constraints. The material and human orders both respond to mandates to explore huge but bounded possibilities within a gifted and undetermined freedom. 


\section{The Phenotype-Genotype Structure of Evolution, Analogies with Statistical Mechanics and Predictability}

There is a surprisingly parallel, rich and unresolved debate on the degree to which 'random' and 'non-random' processes are active in evolution. Remarkably, the standard neo-Darwinian scheme (Lewontin 1974) also envisages connected structural parallels between 'macrocosmic' and 'microscosmic' worlds. In our age these are respectively the 'phenotype' of organisms (from single-cell bacteria to mammals) and the 'genotype' coded in the polymer of DNA. The current 'evolutionary synthesis' envisions a substrate of random mutations at the level of the genotype undergoing non-random selection at the level of the phenotypes for which they code, through their cumulative effect on the fitness of the organism (that is, its ability to reproduce and so pass on its genetic code, in mutated form, to subsequent generations).

It is sometimes mistakenly thought that processes generated by randomness at their 'microscopic' levels must also display randomness at the 'macroscopic' level, but a brief reflection on the analogously-structured case of fluid dynamics shows that this cannot be the case. In a gas or liquid, the individual molecular motions and collisions are distributed as a random stochastic process (van Kampen 1981), yet the emergent fluid dynamics is governed by a deterministic spatio-temporal relationship - the Navier-Stokes equation (Batchelor 1967). It is at first sight counterintuitive that in this way 'order arises out of chaos', but since the early statistical mechanics of Boltzmann and Gibbs of the mid $19^{\text {th }}$ century, it has been understood how randomness at the microscopic, and order at the macroscopic, level can be reconciled.

There are two reasons for the apparent paradox that deterministic outcomes at an emergent length and time-scale can arise from non-deterministic and random events at the microscopic scale of the same system. The first is simply that extremely large numbers of particles support a statistical behaviour with a well-defined mean, around which fluctuations are relatively small (it is possible, in many cases, to make this statement mathematically precise, so that typically the size relative to its mean of 
the fluctuations of a property of $N$ particles reduces as $1 / \sqrt{N}$ ). A cloud of diffusing molecules in a gas liberated from a local source, for example, displays a 'Gaussian distribution' of density as it expands, in spite of the unpredictable collisions of each of those molecules. The second reason for large-scale emergent directionality is that there are typically new constraints or 'boundary conditions' that impose at these scales, whose causal effect works in a 'top-down' manner on the microscopic variables. A simple example in the case of gas and fluid dynamics is the effect of confining walls of the chambers containing them. More complex and subtle examples of emergent constraints that both govern microscopic degrees of freedom and also shape large-scale properties also exist. A set of examples recently attracting the attention of the philosophical discussion of emergence is characterised by 'long range topological order' (McLeish et al. 2019), a phenomenon widespread in physics from quantum mechanics (where it is responsible for the strange behaviour of surface electrons in high magnetic fields and low temperatures) and polymer physics (where it can govern the difference between fluid and solid phases at the macroscopic level).

That evolution may be mapped onto the statistical physics that describes such phenomena in gases, liquids and such more complex condensed matter systems offers by analogy one route by which evolutionary order, and even its directionality, may emerge from the apparent chaos of local random mutation. The 'fitness landscape' for the viability of the organisms, for which the mutating genomes code, constitutes a large-scale set of constraints analogous to the chamber and channels of fluid flow. That fitness is, in turn, induced in part by physical and chemical constraints such as the laws of optics (so that evolving eyes must respect, for example, the properties of refraction, absorption and scattering). On the other hand, the large number of individuals in a species, each delivering random mutations on reproduction, permit the statistical definition of means and variances in phenotypical properties, allowing that a measure of predictability arises in the limit of large numbers within evolutionary networks (even if the numbers are not typically as large as those encountered in thermodynamic systems). These two ways of mapping the statistics of large numbers, and the large-scale 
emergent dynamics within constraints, go a long way towards explaining the phenomenon of evolutionary convergence (Conway Morris 2003), by which similar or even identical phenotypes on scales from species to organs to individual protein molecules, have independently evolved to address the demand of the same function (the locus classicus of convergent evolution is the simple lensed eye, which had independently evolved at least 12 times).

There is significant evidence, however, that many evolutionary cases are more complex than such a straightforward mapping to statistical mechanics would suggest. Some simple phenotypical distributions have been shown recently not to arise through any selective advantage of fitness, but merely to represent the statistical number of genotypes to which they correspond. Such dominance of 'genotypic entropy' emerges in RNA secondary structures, for example (Schaper and Louis 2014). In many such examples, the number of genotypes that correspond to expressible genotypes can be very large indeed, so biasing the appearance of those phenotypes independently of their fitness. Furthermore, the kinetics of exploration of the genotype space are also highly constrained by the genotypic entropy, so that highly-represented phenotypes may be discovered and expressed while fitter solutions are completely bypassed by the evolutionary process. There is a degree of semantic play around ascribing this genotypic entropy dominated process as 'random' of course, for precisely the reasons given for the emergent determinism of fluid dynamics. For the size, shape and topology of the genotype-phenotype map, together with the random microscopic mutation, conspire, as do the boundary conditions for fluids, to generate a determined evolutionary history with a high degree of certainty.

On the other hand, there is considerable evidence that mutation rates are non-random by over an order of magnitude, depending, for example, on the degree to which the corresponding genes are expressed (Martincorena et al. 2012). The evolution of mutation rates in bacteria, for example, conveys adaptational advantages through correlation with externally-imposed stresses (Engelhardt and Shakhnovich 2019). Such environmental dependence of mutation rate alone may not intuitively appear to induce a directionality to evolutionary drift, but, in a different biological context, the dependence on 
local nutrition concentration of the rate at which bacteria reset ('mutate') the direction of their swim is precisely the strategy by which they bias an otherwise random swimming kinetics towards regions of high nutritional worth. The same rate-control of directional bias will obtain for random 'swimming' in genotype spaces.

The point to draw from these recent examples in evolutionary biology is that the fitness and fruitfulness of organisms, as well as the efficiency with which they explore the high dimensional space of structural possibilities and the robustness with which they respond to environmental stress, depend on a subtle interplay of random mutation at the microscopic/genotype level and higher-level structures of topology and encoded rule. In some cases these multiple levels of emergent structure give rise to highly directional evolutionary dynamics that, while freely explored, is anything but 'random'.

\section{The Gift of Freedom and the Mandate to Be Fruitful: a Theology of Evolution}

What can we make from reading these two narratives together, of 'reading Wisdom (long) after Darwin' (Barton and Wilkinson 2009), if you will? One of the set of central conclusions of Faith and Wisdom in Science (McLeish 2014) concerning the shape of a 'theology of science', was that a respectful appreciation of the balance between and interplay of order and chaos would be central. It is worth quoting two paragraphs (from chapter 7 p.183):

This paradoxical programme of science to comprehend chaos, signalled by its realisation that chaos is part of the creation of emergent structures in the world, rather than their destroyer, shares an unmissable resonance with the part played by order and chaos in the biblical narrative we have also been following. Recall the earliest strands of the creation stories in the Proverbs and Psalms: our surprising observation was that they identified the central creative act not so much the summoning of matter from nowhere and nothing but as the ordering of the elemental deeps, the chaotic threat of the waters, and the drawing of boundaries that endow the cosmos with order. Just as the fundamental creative act is one of ordering, so the fundamental energy that drives it is the 'Word'. 
God, or Wisdom, speaks - and the floods retire, the Moon marks the seasons, the sun rises and sets. The formal and developed account of Genesis begins with an idea of formless chaos receiving day-by-day the imprint of structure: we are reminded of the visual poetry of Job as a jagged horizon emerges from darkness in the morning light as if stamped out by a seal.

But the theological narrative of chaos and order is far more complex and interesting than a simple triumph of one over the other. God is not only the shaping force of order, he also unleashes (e.g. in Jeremiah) the forces of thunder, clouds, lightning and wind. There is an uncomfortable undercurrent of pain and puzzlement here. The ordered and productive work of the farmer described by Isaiah can be undone in a moment by the uncontrolled flood that breaks over the river banks, or by the ravages of forest fire. Yet these have no other source that the creator himself. The most detailed articulation of the paradox is of course woven into Job's dialogues. Job longs to understand the apparent lack of justice in his own story, but perceives it written large on the backdrop of his global theatre, where the forces of creation itself wreak destruction apparently at random. His universal perception becomes his universal projection - his planetarium roof diffuses the images of his argument. His accusation that God is out of control of creation, just as he is out of control of justice in the lives of individuals, drives the long journey through the dead-end arguments with his friends, illuminated though they are with occasional glimpses of something deeper. The forces of the wind and clouds, the lightening and flood, become recurring metaphors for the inner energy and life of the physical world that must be channelled, or given a 'way', rather than entombed or left to unbridled destruction. There is a subtle handling of 'knowledge' throughout the journey, and its distinction from its dual, 'understanding'.

In the light of our readings in Wisdom and in evolutionary theory, we now perceive another mistaken aspect in Job's worldview. He sees the chaotic lack of apparent control in the 'microscopics' of flood, disease and lightning, but fails to perceive the guiding pathways (the derek) of emergent structure. He feels the force of their energies as threatening and damaging, but has forgotten the creative energies by which the dynamics of the waters and air unfold the possibilities of the created order. Two of the themes of the 'Lord's Answer' of Job 38-42, the litany of nature-questions that effects 
a cure to Job's anger and despair, are those of holism and decentralisation. The sheer universal coverage of its survey of the wild world, together with its explicit long-distance viewpoints of migrating birds, entire astronomical constellations, and distant mountain ranges outlined against the dawn, force the reader (with Job) to draw back until the macroscopic shape of the cosmos comes into view. In the same way, the text at the close of Wisdom draws back from the elemental shifts of harmonic resonance to the mutation of species, and finally to a view expansive enough to capture the recapitulation of the original creative act by which the waters and the land separate (cf. the introductory verses of Psalm 104).

There is another mode however, apart from the move to decentre, in which the creation, both human and non-human, responds to the creative act, that is thrown particularly into relief by the narratives of the Exodus in Wisdom and the Darwinian story of the exploration of the tree of life - the response to the gift of freedom. Words re-echoing throughout this discussion are uttered by God to Noah at an earlier re-creation by reordering of land and sea: 'Be fruitful and increase in number; multiply on the earth and increase upon it' (Genesis 9:7). The gift of freedom, and the command to fill all available habitable niches (I choose loaded, but not inappropriate, language) is an extension of the original mandate to Adam. The experience of constrained freedom is the working out of same command to exercise the creative coupling of freedom-in-constraint towards the trees in the garden (Genesis 2:16). The story of release into freedom is a leitmotif of the Biblical narrative ${ }^{13}$ - and at each and every point the moral, national and representative freedom of God's people to multiply fruitfully (within moral, ethical and legal boundaries) is paralleled with the illustration of constrained freedom within nature, and the relation of humans to it. The exploration of animal and vegetable as food (Genesis 2), the sign of the rainbow as constrained waters (Genesis 9), and the parting of waters as the natural permissive act of granting political freedom (Exodus 14) all

13 Almost ubiquitously in Biblical literature freedom is adjectival, so 'free' - חמשי is used in $J o b$ of a servant from a master (3:19) and of the wild ass (39:5), and also of the freedom of the oppressed (e.g. Isa 58:6). 
display theo-political and natural concomitants. The final extension of that natural reflection of exploratory freedom into the transmutation of species themselves (Wisdom 19) ought to leave readers of this tradition in no state of surprise when encountering just this constrained exploration of freedom within biological evolution.

Just as in Genesis 3, and primarily in the extended discussion of Job however, there are painful consequences of freedom. A people free to multiply and cover the earth may choose to do so in violation of the moral constraints imposed on them, to their own and others' cost, and to the detriment of the land. Similarly there are inevitable concomitants to the freedom to explore all possibilities at the level of nature's evolutionary substrate, in terms of the darkened and damaged relationship of humankind to the material world of our environment. Mutual harm, exemplified by environmental damage and species extinction on the one hand and viral pandemics on the other, constitutes the shadow side of a created order (Russell 2013) still in need of healing. The Answer to Job does not question the existence, and the painful consequences of disease, earthquake and lightning, nor explain away the effect that these forces have had upon his own life. Job is, however, asked to put himself in the place of a creator of worlds (Job 38:4), and to consider the place of Wisdom in the wildness of the cosmic, atmospheric and animal world. It is as if God offers Job an alternative world, one as safe and stilled as a stone or unmoving block of ice, but in consequence every bit as dead. The freedom of exploration that gives life is likewise not uncontrolled but flows within boundaries.

Both Job and Wisdom, finally, support a thread of another, connected, desire accompanying that of freedom from captivity to fruitful occupation of the land, the wish to be reconciled to the tension between the glory of order and the shadow-side pain of chaos, and the negotiation of the microscopic and macroscopic. In addition to the gift of freedom to explore the ways in which humankind may creatively be the People of God, and to possess the land in a mutually fruitful relationship, there is longing for justice and vindication. Job demands a courtroom appearance of God throughout the cycles of speeches in which he protests his innocence and rails against the injustice of the 
Creator (Job 31:35-37). In the Exodus narrative recapitulated in Wisdom, it is the people of Israel who are under a foreign yoke of injustice who long for liberation, and for the vindication that it would symbolise (Exodus 5:22,23). In both cases there is an implicit narrative warning to be careful for what one wishes in one's just indignation, significantly both linked to the punishing physicality of the land. Job suffers from its wild forces (albeit blind to their hidden and essential creative powers of life), and the brutal experience of Sinai soon causes the Exodus people to long for the old days of captivity.

Here we have closely parallel narrative material that may help us negotiate the common judicial response to the evolutionary exploration of the biological tree of life. The same processes that lead to the glories of swimming dolphins, soaring eagles, intricate types and structures of spiders' silk, and the capacities of human minds, also deliver parasites, predators and viruses. Although these are demonstrably inherent to the exploration of life's possibilities, and to the special opportunities of care and mutual sustainability offered to the species of homo sapiens within the biological economy, they famously struck Darwin as abhorrent (Darwin 1856); their final sweeping away in a renewed creation is a sustained hope in both $J o b$ (Job 5:23) and the prophets (Isaiah 11:6ff). Pauline language comes to our poetic assistance in the face of this tension: we want to say that creation groans at present (Romans 8:22), for we see, or think we see, in this long tradition of hope for justice, how things could be otherwise. The 'crossshaped' form of a reconciliation between the driving, powerful and painful creativity of evolution, and a fruitful and free relationship with nature and its Creator, as in Paul's implicit reference to childbirth and its resonance with Genesis 3, begins to take shape. The justice of the second Person of the Trinitarian God sharing in, and transforming, the physical order, by embodying in a yet anticipated and far greater form, the 'new attuning of elements' of Wisdom, by dying to the old key, and being raised to the new, points, as does a 'wisdom/freedom theology of evolution' itself to a future in which the world is not only in harmonious inter-relationship, fruitful in its co-creativity of the divine and the divine image in humankind, but that this is achieved justly. 
There are, not unexpectedly, strong resonances in the wisdom/freedom approach to a theology of evolution I have outlined here, to a number of other lines of reasoning in over a century of previous post-Darwinian theology (reviewed helpfully in e.g. Barton and Wilkinson 2009 for earlier narratives and Russell 2013 for more recent). The Trinitarian aspects of this account echo, albeit far less fully and deeply, the work of Denis Edwards (1999), and the eschatological and theodicial dimensions the approaches of Christopher Southgate (2008) and Francisco Ayala (2007). The narrative drama implicit in the unfolding of evolutionary creation as a story of possibility, realised and unrealised, is deftly and deeply handled in the 'theodrama' approach of Celia Deane-Drummond (2009). Of course the tradition of 'theistic evolution' starts with Darwin himself, and late $19^{\text {th }}$ century theological responses such as those of Aubrey Moore, who famously observed that Darwin 'under the guise of a foe, did the work of a friend' (cited in McGrath 2013). However, previous approaches have not drawn on the significance of the Wisdom text as a scriptural tradition that contributes to a preparation of mind far more accepting of the material and natural shifts, even radical shifts, that evolution by natural selection requires. Nor have they, in consequence, identified the implicit duality of natural scale in the wisdom literature that reflects the microscopic and macroscopic scales of imagination that provide a historically-rooted framing to an atomistic science, but turns out to be surprisingly ancient. Finally, reading the modern narrative of genotype and phenotype, against a background of the tradition of scriptural wisdom, provides a greater grasp of the locus of the tension between chaos and emergent order that both hold central. The scriptural tradition allows this narrative, in turn, to be situated in a relational theology of science that has a particular place, and co-creative responsibility for humankind.

\section{References}

Alter, Robert. 1985. The Art of Biblical Poetry. New York: Basic Books.

Ayala, Francisco J. 2007. Darwin's Gift to Science and Religion, Washington, DC: Joseph Henry Press. 
Barton, Nicholas H., Coe J. B. 2009. “On the application of statistical physics to evolutionary biology.” Journal of Theoretical Biology 259, 317 - 324.

Barton, Stephen C., and David Wilkinson. 2009. Reading Genesis After Darwin. Oxford: Oxford University Press.

Batchelor, George Keith. 1967. An Introduction to Fluid Dynamics, Cambridge: Cambridge University Press.

Batnitzky, Leora, and Ilana Pardes. 2014. The Book of Job: Aesthetics, Ethics, Hernameutics. Berlin: De Gruyter.

Brooke, John Hedley. 1991. Science and Religion - Some Historical Perspectives. Cambridge: Cambridge University Press.

Clines, David J. A. 1989, 2006, 2011. World Biblical Commentary: Job, 1-20, 21-37, 38-42, Nashville: Thomas Nelson.

Conway, Morris Simon. 2003. Life's Solution: Inevitable Humans in a Lonely Universe. Cambridge: Cambridge University Press.

Darwin, Charles R. 1856. letter to Joseph D. Hooker, available at http://www. darwinproject.ac.uk/entry-1924 (accessed 20.3.2020).

Deane-Drummond, Celia. 2009. Christ and Evolution: Wonder and Wisdom. Minneapolis: Fortress Press.

Edwards, Denis. 1999. The God of Evolution: A Trinitarian Theology. New York: Paulist Press.

Engelhardt, Dalit, \& Eugene I. Shakhnovich. 2019. "Mutation rate variability as a driving force in adaptive evolution.” Physical review. E, 99(2-1), 022424.

Goff, Matthew J. 2007. Discerning Wisdom: the Sapiential Literature of the Dead Sea Scrolls. Leiden: Brill.

Habel, Norman C. 1985. The Book of Job. Old Testament Library. London: SCM Press. Habel, Norman C. 2001. “'Is the Wild Ox Willing to Serve You?' Challenging the Mandate to Dominate." In The Earth Story in Wisdom Traditions, edited by Norman C. Habel and Shirley Wurst, 179-189. Sheffield: Sheffield Academic Press.

Harrison, Petter. 2015. The Territories of Science and Religion. Chicago: University of Chicago Press.

Lewontin, Richard C. 1974. The Genetic Basis of Evolutionary Change. New York: Columbia University Press.

Martincorena, Iñigo, Aswin Seshasayee, Nicholas Luscombe. 2012. "Evidence of non-random mutation rates suggests an evolutionary risk management strategy.” Nature, 485, 95-99.

McGrath, Alister E. 2013. Darwinism and the Divine: Evolutionary Thought and Natural Theology. Hoboken: John Wiley \& Sons.

McLeish, Tom. 2014. Faith and Wisdom in Science. Oxford: Oxford University Press. 
McLeish, Tom C.B., Tom Lancaster and Mark Pexton.2019. "Emergence and Topological Order in Classical and Quantum Systems”, Studies Hist. Phil. Mod. Physics, 66, 155-169.

Moore, Aubrey. 1891. “The Christian doctrine of God.” In Lux Mundi, edited by Charles Gore, 41-81. London: John Murray.

Neiman, Susan. 2016. The Rationality of the World: A Philosophical Reading of the Book of Job, https://www.abc.net.au/religion/philosophical-reading-of-the-book-ofjob/11054038 (accessed 20.3.2020).

Ricoeur, Paul. 1991. "Hermeneutics and the Critique of Ideology.” In From Text to Action: Essays in Hermeneutics II, trans. Kathleen Blamey and John B. Thompson, 270-307. Evanston: Northwestern University Press.

Russell, Robert John. 2013. “Recent theological interpretations of evolution.” Theology and Science, 11, 169-184.

Schaper, Steffen, Ard A. Louis. 2014. “The Arrival of the Frequent: How Bias in Genotype-Phenotype Maps Can Steer Populations to Local Optima.” PLoS ONE 9(2): e86635.

Sinnott, Alice M. 2001. “Job 12: Cosmic Devastation and Social Turmoil.” In The Earth Story in Wisdom Traditions, edited by Norman C. Habel and Shirley Wurst, 78-91. Sheffield: Sheffield Academic Press.

Southgate, Christopher. 2008. The Groaning of Creation, Louisville: John Knox Press. van Kampen, NicoG. 1981. Stochastic Processes in Physics and Chemistry, Amsterdam: North-Holland.

Winston, David. 1971. “The Book of Wisdom's Theory of Cosmogony.” In. History of Religions, Vol. 11, No. 2, edited by Paul Copp \& Christian K. Wedemeyer, 185-202. Chicago: The University of Chicago Press. 